TITLE:

The 9Be $(\mathrm{d}, \mathrm{t})$ 8Be and 9Be $(\mathrm{d}, \mathrm{a}) 7 \mathrm{Li}$ reaction in the Energy Range from 12.17 MeV to 14.43 $\mathrm{MeV}$ (Abstract_要旨 )

AUTHOR(S):

Tanaka, Seiji

\title{
CITATION:
}

Tanaka, Seiji. The 9Be (d,t) 8Be and 9Be $(\mathrm{d}, \mathrm{a}) 7 \mathrm{Li}$ reaction in the Energy Range from 12.17 MeV to 14.43 MeV. 京都大学, 1978 , 理学博士

ISSUE DATE:

1978-11-24

URL:

http://hdl.handle.net/2433/221985

RIGHT: 


\section{【 $34 】$}

氏 名田 虫 誠 た

学位の種類理 学 博士

学位記番号理 博 第 540 号

学位授与の日付昭 和 53 年 11 月 24 日

学位授与の要件学位 規 則第 5 条第 1 項該 当

研究科. 專攻理学研究科物理学第二専攻

学位論文題目 The ${ }^{9} \mathrm{Be}(\mathrm{d}, \mathrm{t}){ }^{8} \mathrm{Be}$ and ${ }^{9} \mathrm{Be}(\mathrm{d}, \alpha){ }^{7} \mathrm{Li}$ Reaction in the Energy Range from $12.17 \mathrm{MeV}$ to $14.43 \mathrm{MeV}$

(入射エネルギー領域 $12.17 \mathrm{MeV}$ 乃至 $14.43 \mathrm{MeV}$ における ${ }^{9} \mathrm{Be}(\mathrm{d} . \mathrm{t})^{8} \mathrm{Be}$ 及び ${ }^{9} \mathrm{Be}(\mathrm{d}, \alpha){ }^{7} \mathrm{Li}$ 反応)

論文調查委員教授柳父环治教授小林晨作教授武藤二郎

\section{論文内容の要旨}

主論文は, ${ }^{9} \mathrm{Be}$ 核に 12 内至 $14 \mathrm{MeV}$ の重陽子を当て，その結果生ずる種々の核反応の中，(d, t ) 反応 と $(\mathrm{d}, \alpha)$ 反応とを同時に観測し, 反応の機構, ${ }^{9} \mathrm{Be}$ 核の構造, 中間状態である ${ }^{11} \mathrm{~B}$ の構造等を考察し たものである。

申請者は自作した ${ }^{9} \mathrm{Be}$ 標的の厚さを 2 種類の方法で検定して、断面積絶対値の誤差を少なくする注意 を払い, 京都大学サイクロトロンで得られる， $12.1 \mathrm{MeV}$ 内至 $14.4 \mathrm{MeV}$ の重陽子を照射し，反応生成 粒子のうち, 重陽子, トリトン, アルファ粒子を, 自作したマルチパラメーターデータ集積回路を用いて， 同時に検出した。この 3 種の粒子のうち, 重陽子に関係した部分は参考諭文 1 に述べられている。主論文 に执いては, 両反応の励起関数, 低高両端の重陽子ェネルギーでの微分断面積の絶対值及び角度依存性等 の測定を， $\left(\mathrm{d}, \mathrm{t}_{0}\right)\left(\mathrm{d}, \mathrm{t}_{1}\right)\left(\mathrm{d}, \alpha_{0}\right)\left(\mathrm{d}, \alpha_{1}\right)\left(\mathrm{d}, \alpha_{2}\right)\left(\mathrm{d}, \alpha_{4}\right)$ の各各の反応につき行なった結果を始め に述べている。これ等の測定結果は, 信頼性の高い, 新しいデータである。

申請者はさらに実験結果を, 歪曲波ボルン近似, ルジャンドル関数展開等の手法及び直接反応, 複合核 反応の概念を適用して解析した結果，

（1）（d，t）反応は主として直接反応の過程で生じている。 ${ }^{9} \mathrm{Be}$ は ${ }^{8} \mathrm{Be}+\mathrm{n}$ の構造を持ち，弱く結合した 中性子を入射重陽子が拾い上げて逃げさるのが (d, t ) 反応の機構である。 ${ }^{9} \mathrm{Be}$ 中の中性子の分光学因子 については従来まちまちの報告があるが, 申請者の採用した, 重陽子の弾性, 非弾性散乱, (d, t ) 反応 の 3 種に最も適合する光学ポテンシャルを求める手法により, 分光学因子は 0.29 であると確定出来る。

(2) (d， $\alpha$ ) 反応は，一度中間状態を経由する反応である。しかし励起関数より見て，この中間状態は， 寿命の長い複合核ではなく, $\alpha+\alpha+t$ の形のクラスター集合体であり，全体として巨大共鳴の状態にある

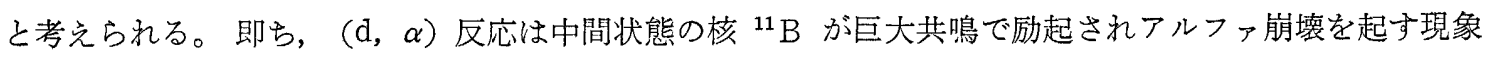
であると解される。また， $\alpha_{0}, \alpha_{1}, \alpha_{2}, \alpha_{4}$ の角分布及び励起関数の挙動から，残留核 ${ }^{7} \mathrm{Li}$ の基底状態， 第 1 ，第 2 励起状態は一つのバンドをなして居るが，第 4 励起状態は異なるバンドに属する。 


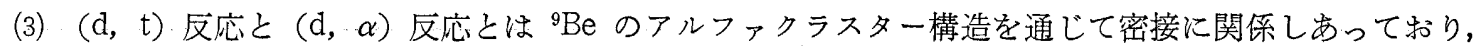
弱く結合された中性子を重陽子が捕獲して逃れ去れば ( d , t ) 反応となり, 核内に重陽子が止まって ${ }^{9} \mathrm{Be}$ 内のアルファクラスター 1 箇と, 中性子, 重陽子とで ${ }^{7} \mathrm{Li}$ 核を作って分裂すれば $(\mathrm{d}, \alpha)$ 反応となる。

といら結論を得ている。

参考論文 1 は, ${ }^{9} \mathrm{Be}$ 核による重陽子の弾性, 非弾性散乱の報告で, その中で得られた光学ポテンシャル が，主論文のデータ解析の基礎となっている。参考論文 2 内至 11 は，主論文の研究に用いられた実験技術， ${ }^{9} \mathrm{Be}$ 飞近接する軽い核の反応と構造の研究を述べている。

\section{論文審査の結果の要旨}

申請者の行なった研究は, ${ }^{9} \mathrm{Be}$ 核に $12.17 \mathrm{MeV}$ 内至 $14.43 \mathrm{MeV}$ の重陽子を当て, 生成する重陽子, トリトン, アルファ粒子を同時に検出して, 弾性散乱, 非弾性散乱, $(d, t)$ 反応, $(d, \alpha)$ 反応の 4 種の 反応相互間の関係を知ろうとしたもので，発想に新鮮味を認められる。

申請者は参考論文 2 に報告されている，小型計算機を用いたマルチパラメーターのデータ集積装置を開 発し, その技術を使って本研究を行った。上記 4 種の反応のうち, 弾性散乱, 非弾性散乱の研究は, 参考 論文 1 に記されているが，その主要な結論は， ${ }^{9} \mathrm{Be}$ の基底状態と第 2 励起状態とは強く結合して居り，こ の強結合をとり入れた解析で始めて最適の光学ポテンシャルを設定出来ること, ${ }^{9} \mathrm{Be}$ の変形因子 $\beta_{2}$ は1. 4 の值を持ち, ${ }^{9} \mathrm{Be}$ は大きく変形しているとされること等である。

$(\mathrm{d}, \mathrm{t})$ 反応及び $(\mathrm{d} ， \alpha)$ 反応の研究に和いて，申請者は入射重陽子のエネルギーを $12.1 \mathrm{MeV}$ よ $14.4 \mathrm{MeV}$ まで変え, 励起関数, 微分断面積の絶対值とその角度依存性とを測定している。これ等の測定 はこのエネルギー領域では始めてで, 測定値はそれ自身新しいデータとしての価值を有して居る。申請者 はさらに, このデータに, 弾性, 非弾性散乱の研究より確定した光学ポテンシャルを適用して解析を行な い, $(\mathrm{d}, \mathrm{t})$ 反応は ${ }^{9} \mathrm{Be}$ 中の弱く結合した中性子を, 入射重陽子が捕獲する反応で, 従って ${ }^{9} \mathrm{Be}$ は ${ }^{8} \mathrm{Be}+$ $\mathrm{n}$ といらクラスター構造を持ち，へリウムを芯とする殸模型は不適当であると結論した。ぬた（ $\mathrm{d} ， \alpha)$ 反応は，その角度分布が注㜔完な $90^{\circ}$ 対称であることを明らかにした後，(d，t）反応とは異なり，一 度中間状態を経由するアルファ崩壞反応であると結論した。しかもこの中間状態は, 励起関数の形, 残留 核 ${ }^{7} \mathrm{Li}$ のバンド構造等を考慮して, パリティが正の巨大共鳴状態であろうと推定し, $(\mathrm{d}, \alpha)$ 反応は, 巨 大共鳴状態に励起された ${ }^{11} \mathrm{~B}$ 核のアルファ崩壊であると解釈した。また $(\mathrm{d}, \mathrm{t})$ 反応と $(\mathrm{d}, \alpha)$ 反応と が泳潼しい断面積を持つことを考慮して， ${ }^{9} \mathrm{Be}$ のクラスター構造がどちらの反応をも規定して居り， $\alpha+\alpha+\mathrm{n}$ の構造を持つ ${ }^{9} \mathrm{Be}$ に重陽子が当って, 中性子を捕獲して逃げ去れば（ $\mathrm{d}, \mathrm{t}$ ) 反応となり, 中性 子と結合して $\alpha+\alpha+\mathrm{t}$ の形となり， $\alpha$ ととが ${ }^{7} \mathrm{Li}$ に結合すれば（d， $\left.\alpha\right)$ 反応となる，と推定してい る。

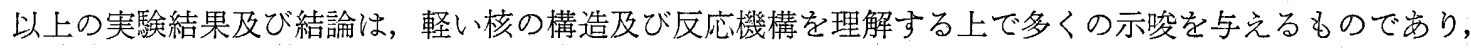
参考論文に示された申請者の研究能力も確実であり, 本論文は理学博士の学位論文として価值あるものと 認める。 